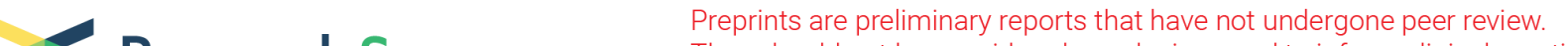 $\begin{array}{ll}\text { Research Square } & \begin{array}{l}\text { They should not be considered conclusive, used to inform clinical practice, } \\ \text { or referenced by the media as validated information. }\end{array}\end{array}$
}

\section{Unveiling metabolic vulnerability and plasticity of human osteosarcoma stem and differentiated cells to improve cancer therapy}

\section{Gerardo Della Sala}

Stazione Zoologica Anton Dohrn Napoli

\section{Consiglia Pacelli}

University of Foggia Department of Medical Area: Universita degli Studi di Foggia Dipartimenti di Area Medica

\section{Francesca Agriesti}

University of Foggia Department of Medical Area: Universita degli Studi di Foggia Dipartimenti di Area Medica

\section{llaria Laurenzana}

IRCCS CROB: Istituto di Ricovero e Cura a Carattere Scientifico Centro di Riferimento Oncologico della Basilicata

\section{Francesco Tucci}

University of Foggia Department of Medical Area: Universita degli Studi di Foggia Dipartimenti di Area Medica

\section{Mirko Tamma}

University of Foggia Departments of Medicine: Universita degli Studi di Foggia Dipartimenti di Area Medica

\section{Nazzareno Capitanio}

University of Foggia Department of Medical Area: Universita degli Studi di Foggia Dipartimenti di Area Medica

\section{Claudia Piccoli ( $\nabla$ claudia.piccoli@unifg.it )}

University of Foggia Faculty of Medicine and Surgery: Universita degli Studi di Foggia Dipartimenti di Area Medica https://orcid.org/0000-0001-9739-4680

\section{Research}

Keywords: oncometabolism, cancer stem cell, metabolic therapy, mitochondria, cisplatin, osteosarcoma, metabolic flux analysis, impedentiometry

Posted Date: June 14th, 2021

DOl: https://doi.org/10.21203/rs.3.rs-613239/v1 
License: (c) (i) This work is licensed under a Creative Commons Attribution 4.0 International License. Read Full License 


\section{Abstract}

\section{Background}

Defining the metabolic phenotypes of cancer-initiating cells or cancer stem cells and of their differentiated counterparts might provide fundamental knowledge for improving or developing more effective therapies. In this context we extensively characterized the metabolic profiles of two osteosarcoma-derived cell lines, the 3AB-OS cancer stem cells and the parental MG-63 cells.

\section{Methods}

To this aim Seahorse methodology-based metabolic flux analysis under a variety of conditions complemented with real time monitoring of cell growth by impedentiometric technique and confocal imaging were carried out.

\section{Results}

The results attained by selective substrate deprivation or metabolic pathway inhibition clearly show reliance of 3AB-OS on glycolysis and of MG-63 on glutamine oxidation. Treatment of the osteosarcoma cell lines with cisplatin resulted in additive inhibitory effects in MG-63 cells depleted of glutamine whereas it antagonized under selective withdrawal of glucose in $3 A B-O S$ cells thereby manifesting a paradoxical pro-survival, cell-cycle arrest in $\mathrm{S}$ phase and antioxidant outcome.

Conclusions

All together the results of this study highlight that the efficacy of specific metabolite starvation combined with chemotherapeutic drugs depends on the cancer compartment and suggest cautions in using it as a generalizable curative strategy.

\section{Full Text}

This preprint is available for download as a PDF.

\section{Figures}


A Mitochondrial Respiration

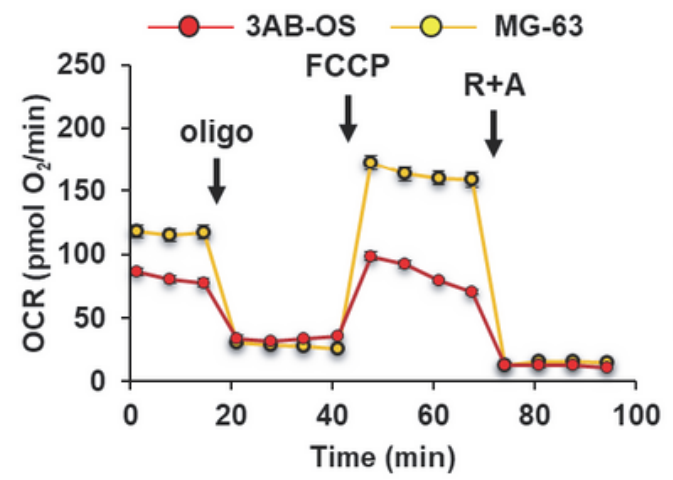

C

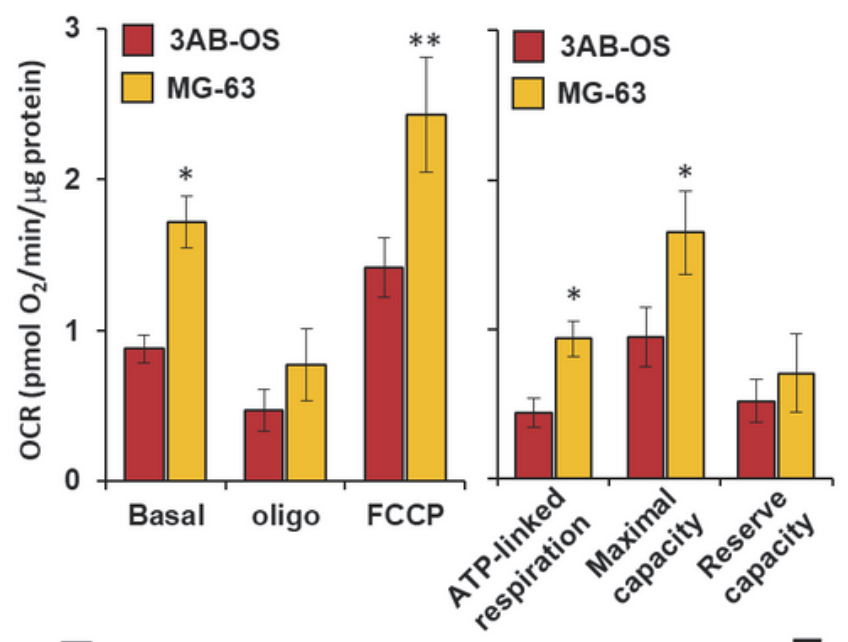

$\mathbf{E}$

Energy map

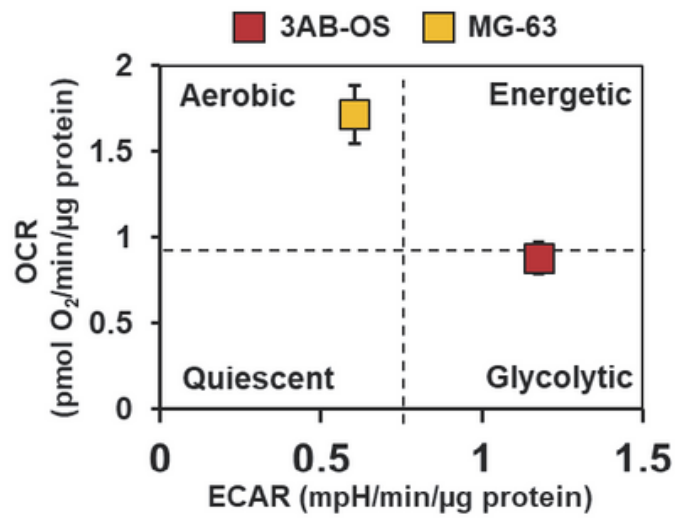

B

Glycolysis

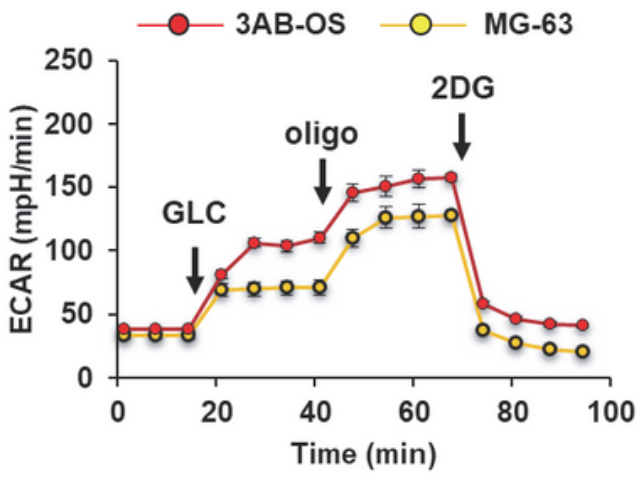

D

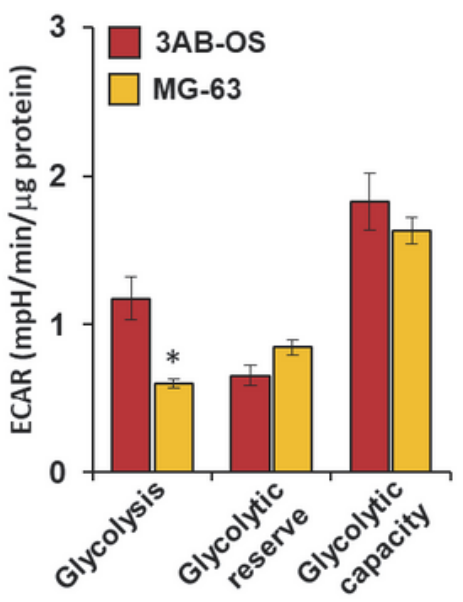

$\mathbf{F}$

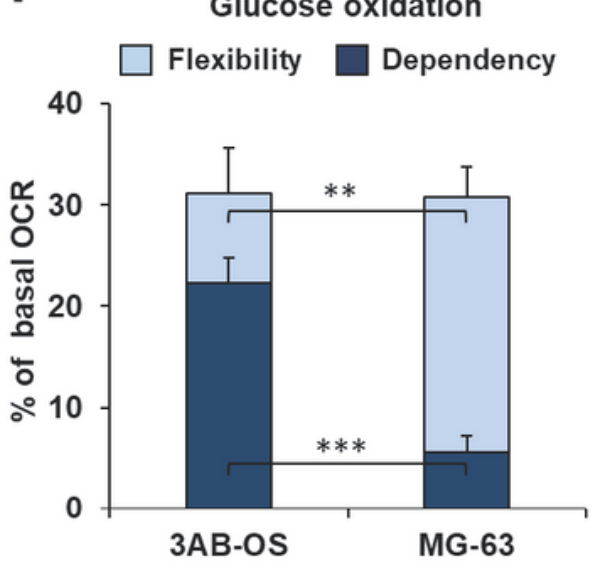

\section{Figure 1}

Comparative metabolic flux analysis of 3AB---OS and MG---63 cells, by using 1 the Seahorse XFe96 Analyzer. (A) Representative profile of mitochondrial respiration stress test assay of 3AB---OS and MG--63 cells in basal condition, in presence of the ATP---synthase inhibitor oligomycin and after addition of the mitochondrial uncoupler FCCP. (B) Representative profile of glycolytic activity stress assay of MG---63 and $3 A B---O S$ cells in presence of saturating amount of glucose (glycolysis), in presence of the glycolysis 
inhibitor 2--- deoxyglucose (reserve), and after addition of the ATP---synthase inhibitor oligomycin (capacity). (C) Statistical analysis of the OCRs measured as in (A). Left panel: histograms showing basal OCR, OCR in the presence of oligomycin, OCR in the presence of FCCP; right panel: histograms showing ATP---linked respiration, maximal respiratory capacity and reserve capacity computed as described in Materials and Methods. The values are means \pm SD of four independent experiments. $* * p<0.05$; $* \star * p<$ 0.01. (D) Statistical analysis of the ECARs measured as in (B). The histograms show basal glycolysis, glycolytic reserve and glycolytic capacity as described in Materials and Methods. The values are means \pm SD of four independent experiments. ${ }^{\star \star} p<0.05 ;{ }^{* \star} p<0.01$. (E) Energy map was obtained plotting basal OCR versus basal ECAR of 3AB---OS and MG---63 cells. (F) Evaluation of mitochondrial glucose usage in 3AB---OS and MG---63 cells, expressed as percentage of basal OCR. Glucose dependency indicates cell reliance on the glucose oxidation pathway to maintain basal respiration. Metabolic flexibility to glucose is the ability of cells to compensate for the inhibition of the glucose oxidation pathway by oxidation of alternative substrates to fuel mitochondrial OxPhos. The values are means \pm SD of three independent experiments. ${ }^{* *} p<0.01 ;{ }^{* \star} p<0.001$. 
A
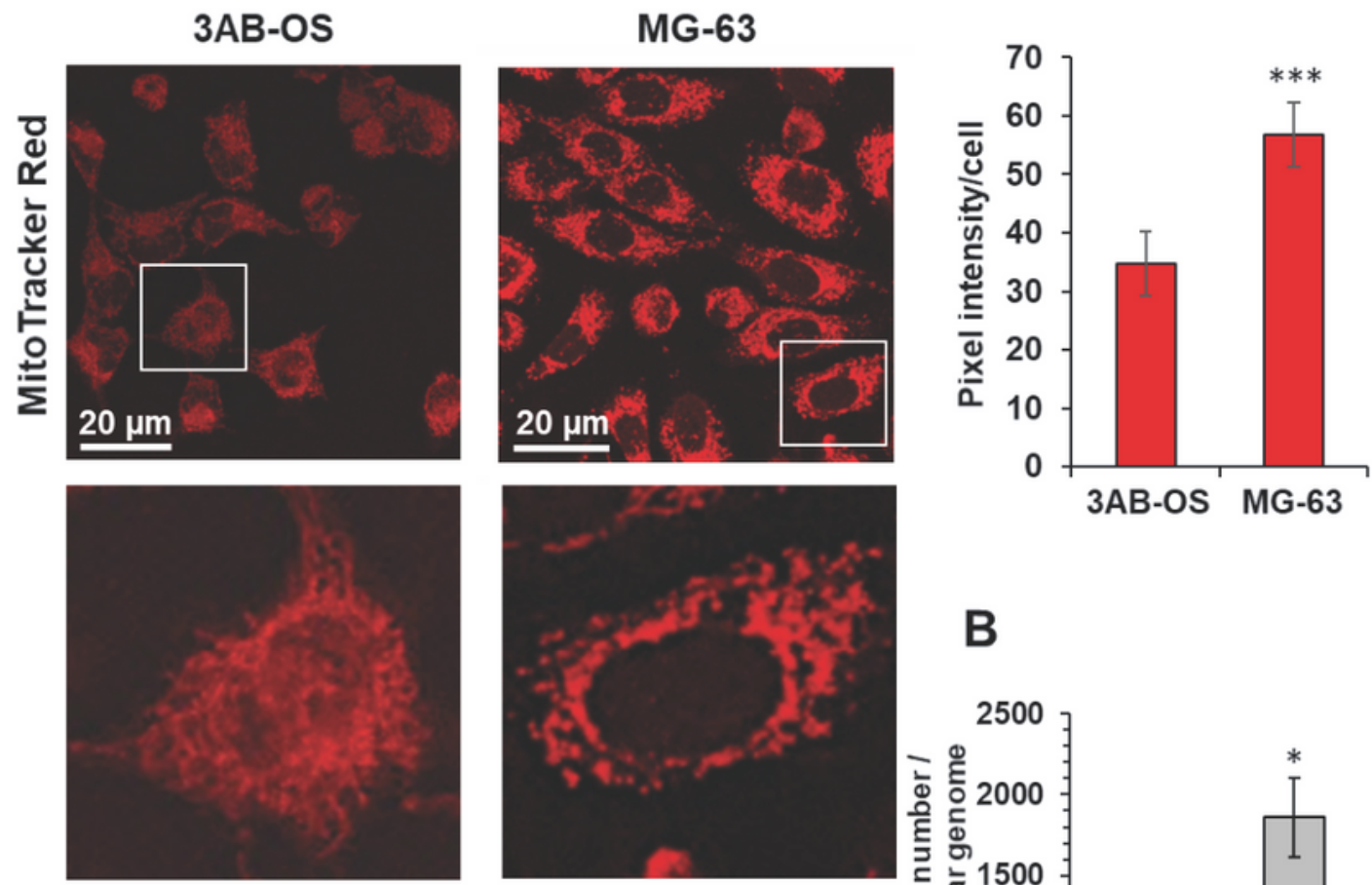

C
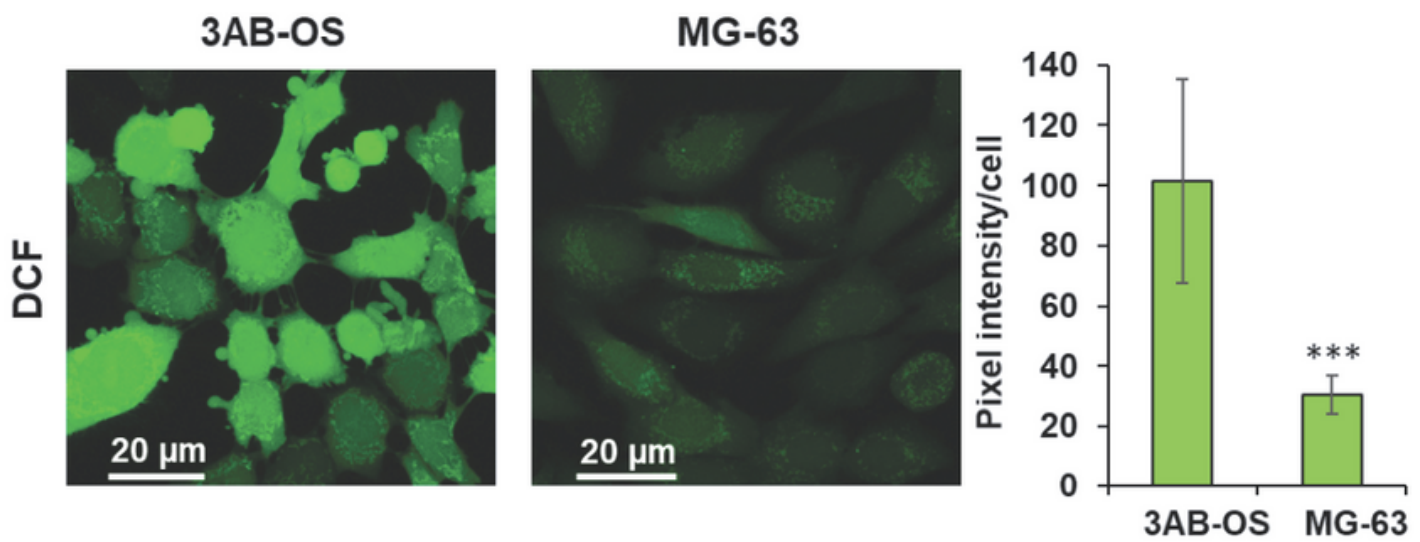

Figure 2

(A) Laser scanning confocal microscopy (LSCM) imaging of mitochondrial morpho---functional parameters in 3AB---OS and MG---63 cells by the fluorescent probe MitoTracker Red. Left panels show representative images and digital magnifications of the squared details. The histogram on the right shows statistical analysis of the MitoTracker pixel intensity per cell; values are means \pm SD of three independent biological replicates; ${ }^{* \star} p<0.001$. Ten randomly chosen optical fields/sample each 
containing about 15 cells were analyzed by ImageJ. (B) mtDNA copy number of 3AB---OS and MG---63 cells assessed by q---RT---PCR; the bar histogram shows values normalized to the nuclear DNA. The values are means \pm SD of three independent experiments; ${ }^{*} p<0.01$. (C) LSCM imaging of cells treated with the reactive oxidant species probe DCF. Left panels show representative images. The histogram on the right shows statistical analysis of the DCF pixel intensity per cell, ${ }^{\star \star \star} \mathrm{p}<0.001$; values are means \pm SD of three independent biological replicates analyzed as in (A).

A
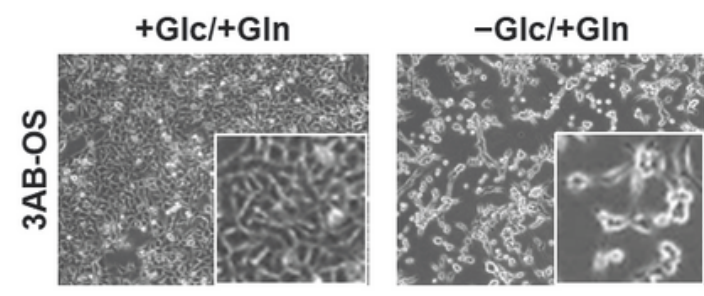

+Glc/-GIn
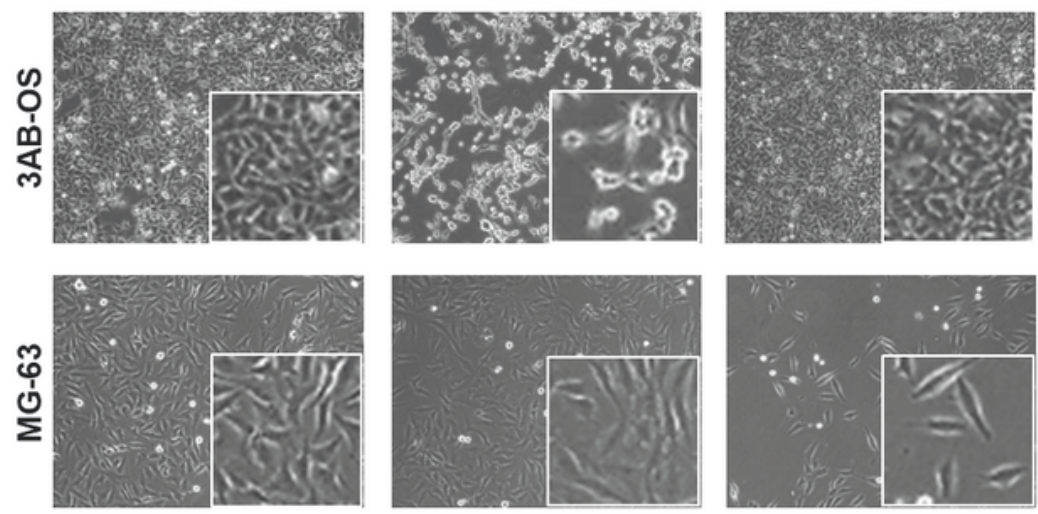

B

GLUCOSE DEPRIVATION
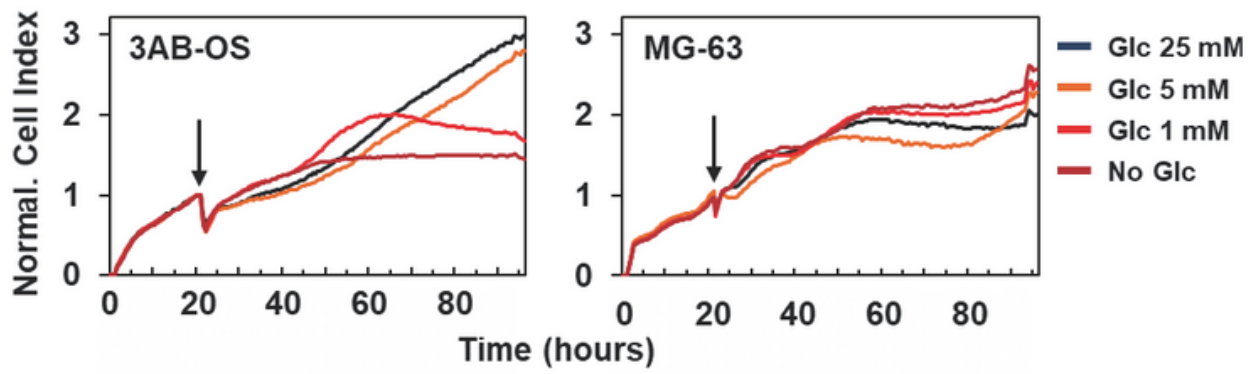

C glutamine deprivation
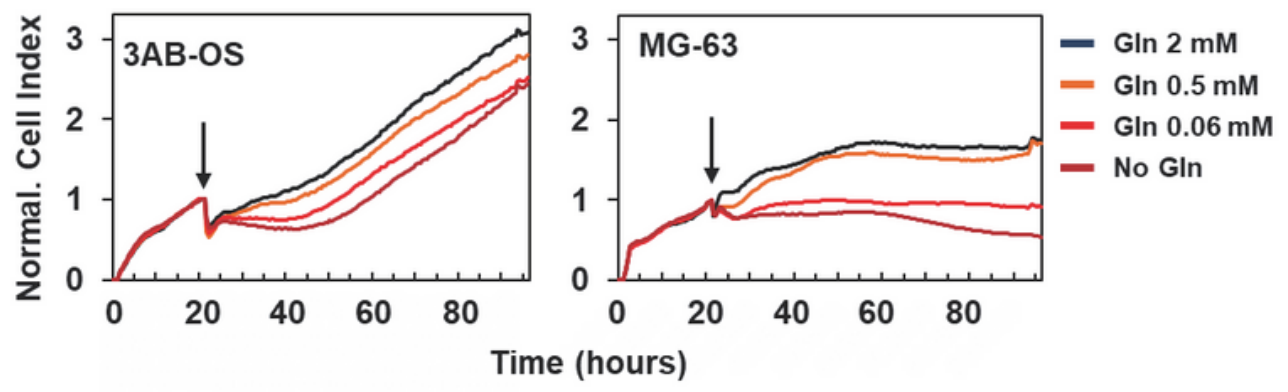

D INHIBITION OF FUEL OXIDATION PATHWAYS

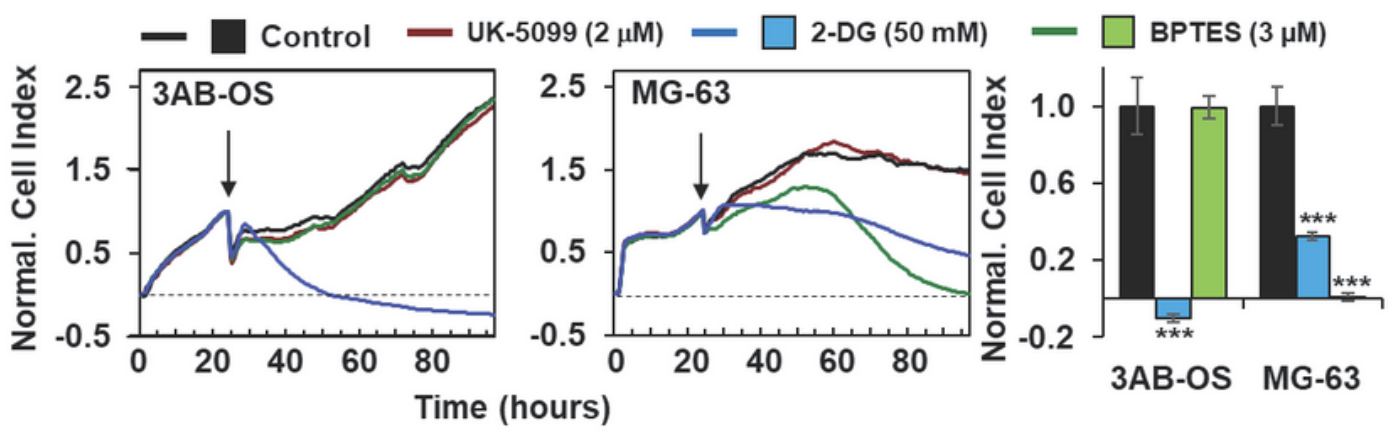

Figure 3 
Effects of nutrient availability and metabolic pathway inhibition on osteosarcoma cell proliferation. (A) Phase---contrast images of 3AB---OS (upper panel) and MG---63 (lower panel) cultured for 48 hours in three different conditions (from the left to the right): $+G l c /+G l n$, complete DMEM medium containing 25 $\mathrm{mM}$ glucose (Glc) and $2 \mathrm{mM}$ glutamine (GIn); +Glc/---GIn, DMEM medium with $25 \mathrm{mM}$ Glc, without GIn; --Glc/+GIn, DMEM medium with $2 \mathrm{mM}$ Gln, without Glc. $(B, C)$ Representative normalized cell index kinetics of $3 A B---O S$ and MG---63 cells exposed to stepwise decrease in Glc or Gln concentration. Cells were grown in complete DMEM medium for approximately 24 hours after seeding. Then medium was changed, and cells were treated for 72 hours with DMEM medium containing different concentrations of Glc (B) or GIn (C) as indicated by the arrows. Each cell index value was normalized just before this starting point. (D) Normalized Cell Index traces of osteosarcoma cell lines incubated with either the glycolytic inhibitor 2---DG $(50 \mathrm{mM})$ or the GLS1 inhibitor BPTES $(2 \mu \mu \mathrm{M})$ or the mitochondrial pyruvate carrier UK---5099 (2 $\mu \mathrm{M})$ for 72 hours. Cells were grown in complete DMEM medium and the day after treated with antimetabolites. The histogram (last graph on the right) displays different sensitivity to 2---DG or BPTES of $3 \mathrm{AB}---\mathrm{OS}$ and MG---63 cells. $\mathrm{NCl}$ values have been normalized to the relevant control. Data are presented as mean $\pm S D ; n=3$. Statistical significances are referred to control. ${ }^{\star \star \star} p<0.0001$. 

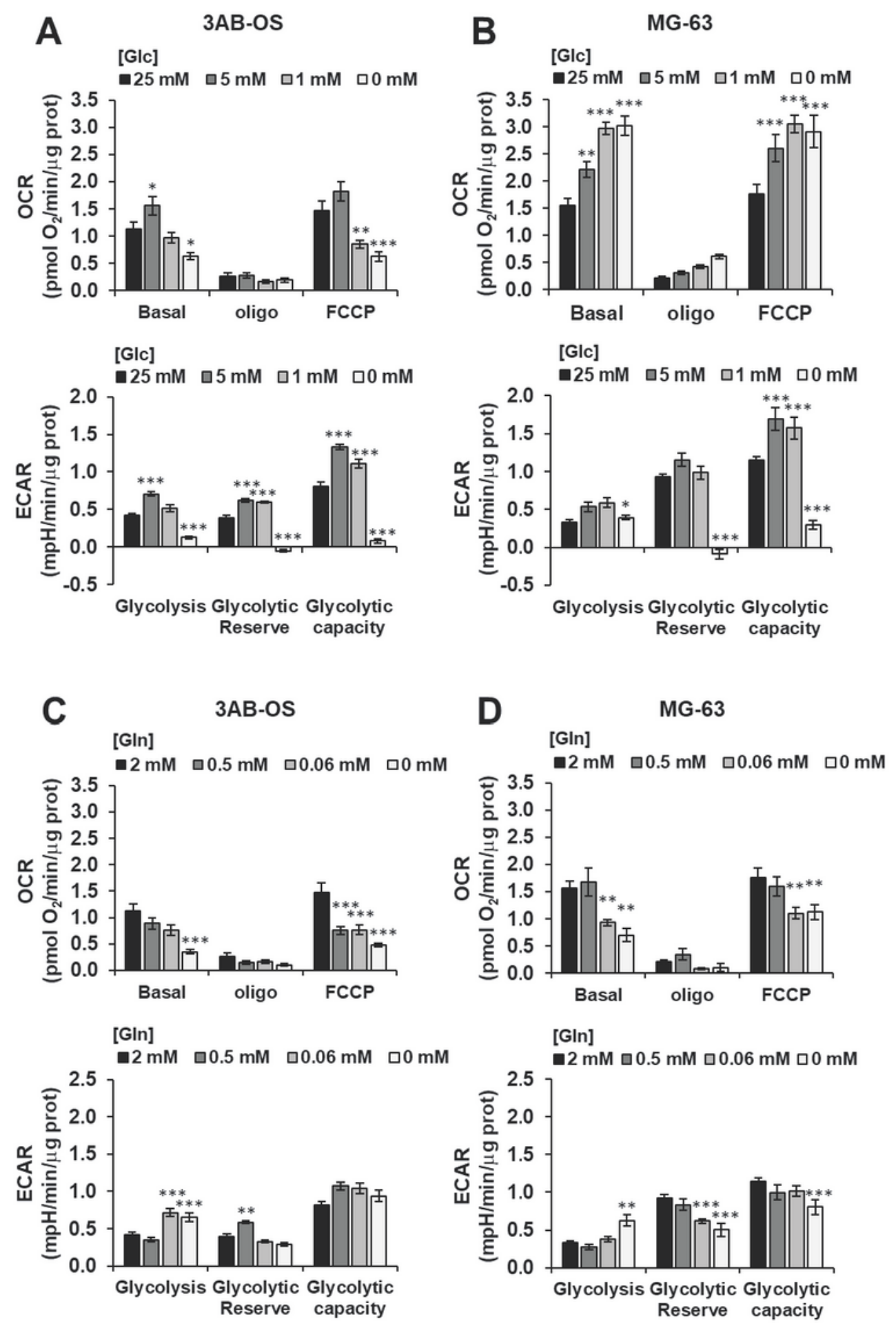

\section{Figure 4}

Effects of nutrient availability on the metabolic fluxes of osteosarcoma cell proliferation. $3 A B---O S(A, C)$ and MG---63 $(B, D)$ were incubated $48 \mathrm{~h}$ with the indicated different concentrations of glucose $(\mathrm{Glc})$ or glutamine (GIn) and OCR and ECAR measured by Seahorse as in Figs. 1A,B. Bars indicate mean \pm SEM of 3 biological replicates each carried out in triplicate. Statistical significances are referred to control; ** $p<$ $0.005, * * * p<0.001$. 
A
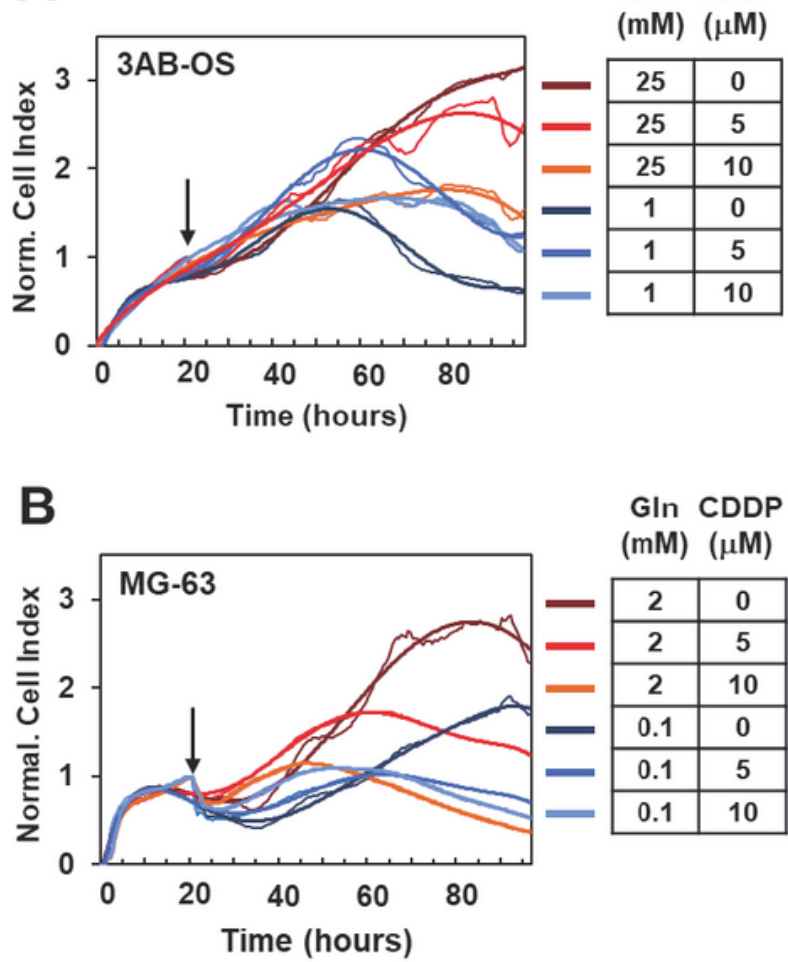

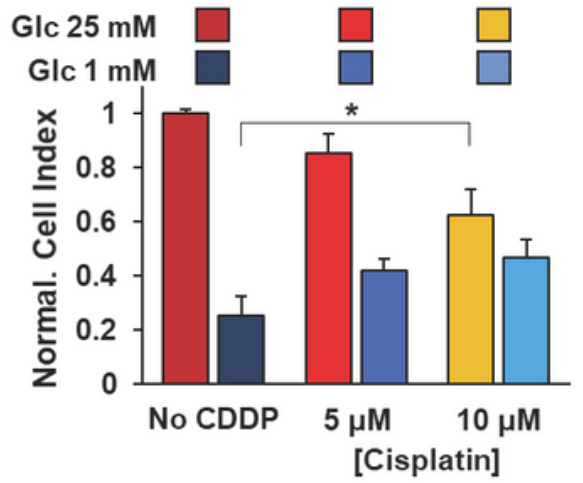

$\mathrm{G} \ln 2 \mathrm{mM}$ Gln $0.1 \mathrm{mM}$

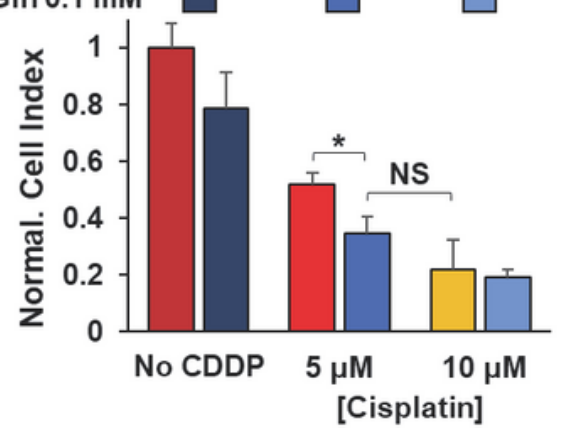

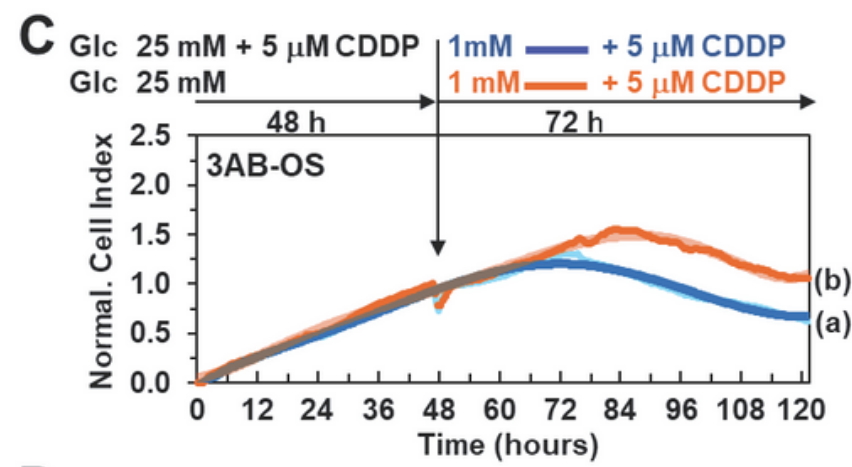

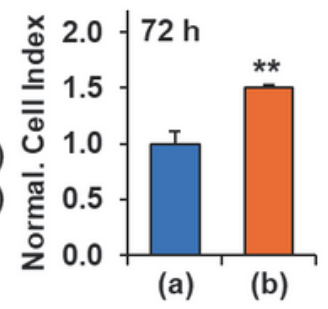

D
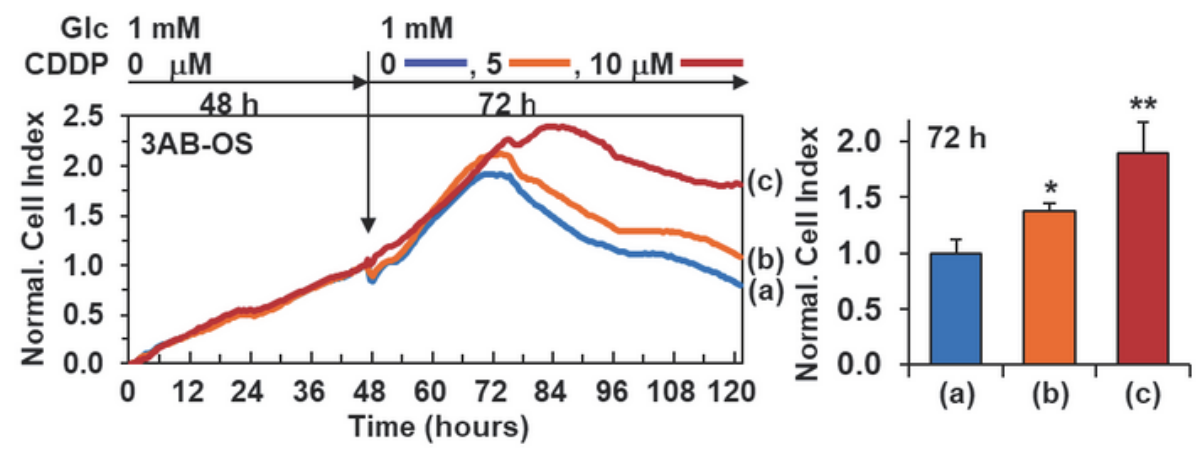

\section{Figure 5}

Cell viability effects of cisplatin combined with energy substrate deprivation. (A) Real---time monitoring of $3 A B---O S$ cell growth after $72 \mathrm{~h}$ treatment with cisplatin in high $(25 \mathrm{mM}) /$ low $(1 \mathrm{mM})$ glucose conditions. Cells were cultured under normal growth condition (DMEM medium with $25 \mathrm{mM}$ Glc and $2 \mathrm{mM} \mathrm{GIn}$ ) for approximately 24 hours, and, after medium change, exposed to 5 and $10 \mu \mu \mathrm{M}$ cisplatin (CDDP) in complete DMEM medium supplemented with either $25 \mathrm{mM}$ or $1 \mathrm{mM} \mathrm{Glc}$. Panel on the left: representative 
$\mathrm{NCl}$ traces. Bar histogram on the right: $\mathrm{NCl}$ values normalized to controls represented by untreated cells (No CDDP), cultured under normal growth condition. Data are presented as mean \pm SD of three independent experiments (biological replicates). ${ }^{*} p<0.05$. (B) Real---time monitoring of MG---63 cells after $72 \mathrm{~h}$ treatment with CDDP in high $(2 \mathrm{mM}) / \mathrm{low}(0.1 \mathrm{mM})$ glutamine conditions. Cells were cultured under normal growth condition (DMEM medium with $25 \mathrm{mM}$ Glc and $2 \mathrm{mM} \mathrm{GIn)} \mathrm{for} \mathrm{approximately} 24$ hours, and, after medium change, exposed to 5 and $10 \mu \mu \mathrm{M}$ cisplatin in complete DMEM medium supplemented with either $2 \mathrm{mM}$ or $0.1 \mathrm{mM}$ Gln. Panel on the left: representative $\mathrm{NCl}$ traces. (B) Bar histogram: $\mathrm{NCl}$ values normalized to controls represented by untreated cells (No CDDP), cultured under normal growth condition. Data are presented as mean \pm SD of three independent experiments (biological replicates). ${ }^{*} p<0.05$. (C) and (D), antagonist effects of glucose shortage and cisplatin administration on 3AB---OS proliferation. (C) Response of CDDP---pretreated $3 A B---O S$ cells to glucose shortage. Left panel, representative growth curves of $3 \mathrm{AB}---\mathrm{OS}$ cells pretreated for 2 days in high glucose $+/---5 \mu \mu \mathrm{M}$ CDDP and then incubated in low glucose $+/--5 \mu \mu \mathrm{M}$ CDDP for 72 hours. Right panel, bar histogram: $\mathrm{NCl}$ values of CDDP---pretreated 3AB---OS cells relative to control (cells not pretreated with CDDP) after 72h treatment. (D) Sensitivity of low---glucose pretreated 3AB---OS cells to CDDP. Left panel,representative growth curves of $3 A B---O S$ cells pretreated with low glucose for 2 days and then exposed to CDDP ( 5 and $10 \mu \mu \mathrm{M}$ ) or vehicle in low glucose nutrient medium for 72 hours. Right panel, 1 bar histogram: $\mathrm{NCl}$ values of low glucose---pretreated $3 \mathrm{AB}---\mathrm{OS}$ cells relative to control (Glc $1 \mathrm{mM}$ ) after $72 \mathrm{~h}$ treatment. All data are presented as mean $\pm S D$ of three independent experiments. $* p<0.05$; $* *<0.01$. Statistical significances are referred to the controls 

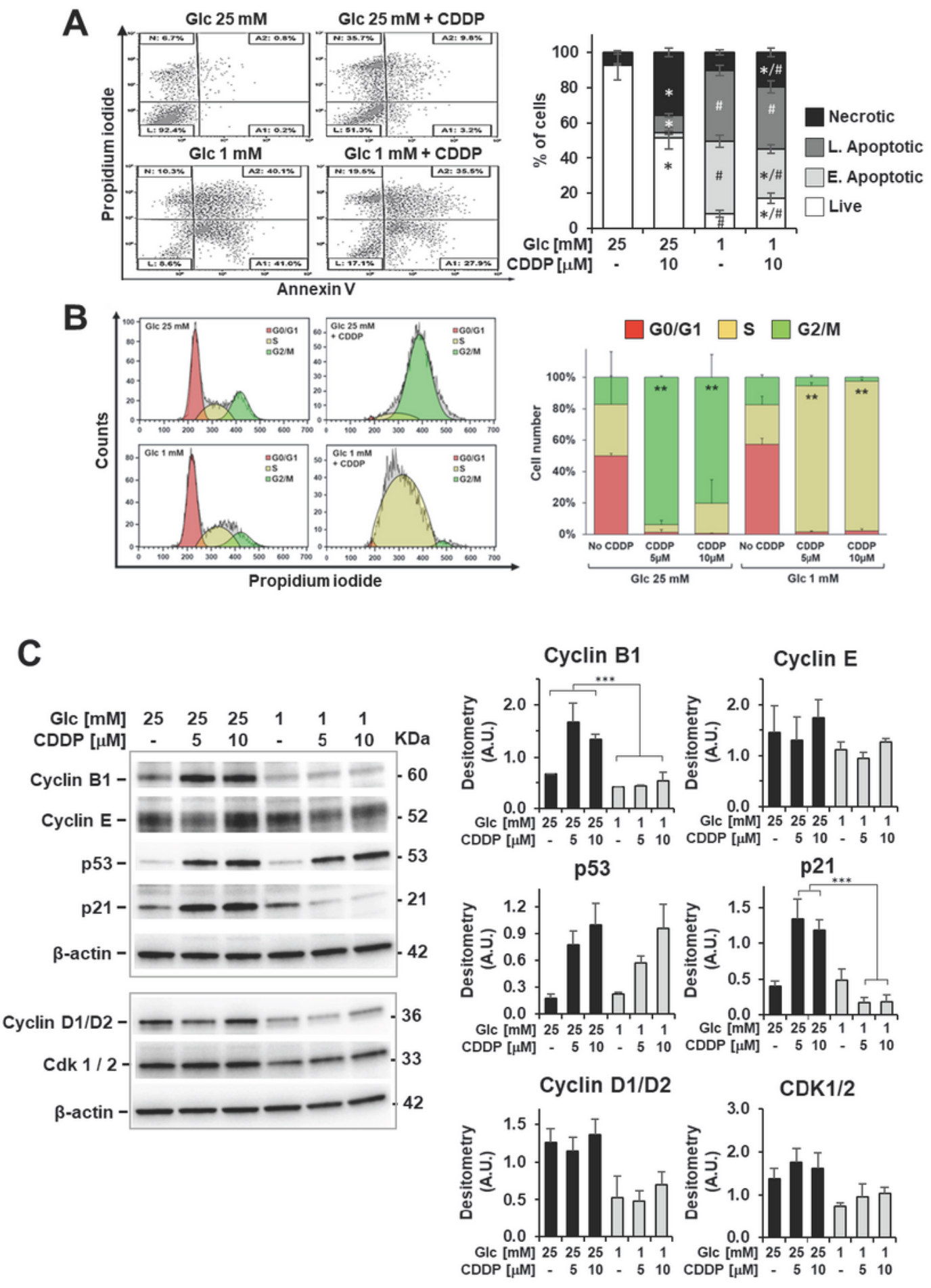

\section{Figure 6}

Cisplatin effects on apoptosis induction and cell---cycle distribution in 3AB---OS cells under high and low glucose growth conditions. (A) Flow cytometric detection of apoptosis and necrosis with Annexin---V--fluorescein isothiocyanate (FITC) and propidium iodide staining in 3AB---OS cells after 72h exposure to $10 \mu \mu \mathrm{M}$ CDDP in high $(25 \mathrm{mM})$ and low $(1 \mathrm{mM})$ glucose. Dot plots on the left show a single representative experiment; histogram on the right shows the statistical analysis of three independent 
biological replicates. Abbreviations: L, live cells; A1, early apoptotic cells; A2, late apoptotic cells; N, necrotic cells. $1 *, p<0.05$ vs cells grown at high and low Glc but in the absence of CDDP; $\#, p<0.05$ vs cells grown at high and low Glc but in the presence of CDDO. (B) Cell cycle analysis through PI staining and flow cytometry of 3AB---OS cells after 48h treatment with $10 \mu \mu \mathrm{M}$ CDDP in $25 \mathrm{mM}$ and $1 \mathrm{mM}$ glucose media. Cell cycle histogram plots show a single representative experiment (left panel). Changes in cell cycle distribution of $3 A B---O S$ cells exposed to CDDP ( 5 and $10 \mu \mu \mathrm{M})$ or vehicle in high and low glucose conditions for 48 hours (right panel). Data are presented as mean $\pm S D ; n=3$. Statistical significances are referred to the relevant controls. ${ }^{*} p<0.01$. (C) Protein expression of cell cycle---controlling factors. $A$ representative cropped Western blotting of total $3 A B---O S$ cells extract is shown; cells were treated at high and low Glc with CDDP as indicated for $48 \mathrm{~h}$. The histograms show statistical evaluation of the densitometric analysis (normalized to $\beta$---actin) for the indicated proteins; bar values are means \pm SEM of three independent experiments. ${ }^{* \star} p<0.0005$. 


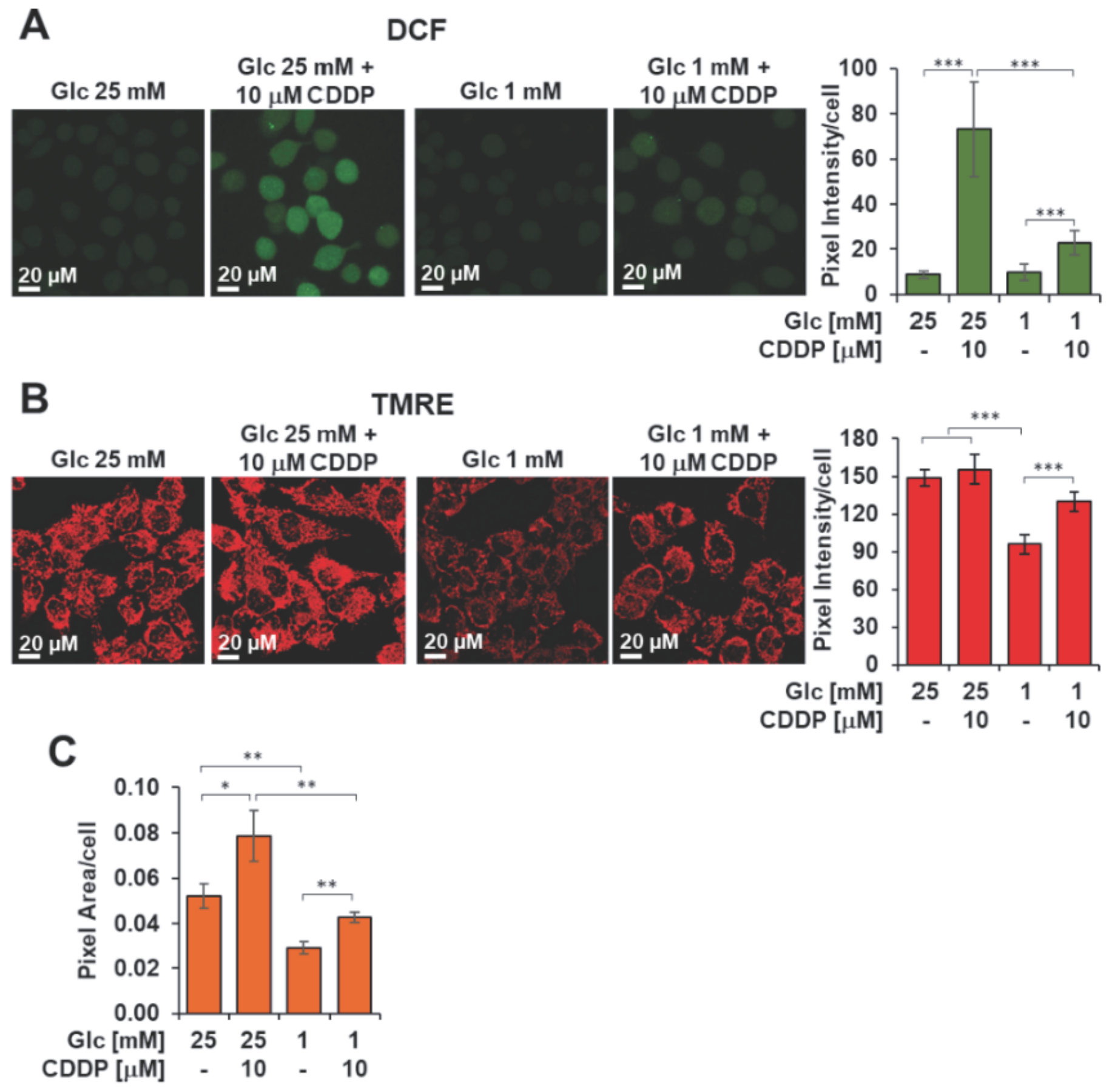

Figure 7

Cisplatin effects on ROS production and mitochondrial membrane potential in 3AB---OS under high and low glucose growth conditions. Cells were treated with the CDDP or vehicle at low and high glucose (Glc) as indicated and analysed after $48 \mathrm{~h}$. (A) Laser scanning confocal microscopy (LSCM) of ROS production by the fluorescent probe DCF. Left panel shows rrepresentative LSCM images. Bar histogram on the right shows statistical analysis of the DCF pixel intensity/cell; values are means \pm SD of 1 three independent biological replicates; ${ }^{* \star} \mathrm{p}<0.001$. Ten randomly chosen optical fields/sample each containing about 15 
cells were analyzed by ImageJ. (B) LSCM analysis of mitochondrial transmembrane potential $(\Delta \Psi \mathrm{m})$ by the fluorescent probe TMRE. Left panel shows representative LSCM images. Bar histogram on the right shows statistical analysis of the TMRE pixel intensity/cell; values are means \pm SD of three independent biological replicates; $* \star * p<0.001$. Ten randomly chosen optical fields/sample each containing about 15 cells were analyzed by ImageJ. (C) Bar histogram showing the overall TMRE---related pixel area/cell; values are means \pm SD of three independent biological replicates; ${ }^{\star} p<0.05,{ }^{\star \star} p<0.01$.

A

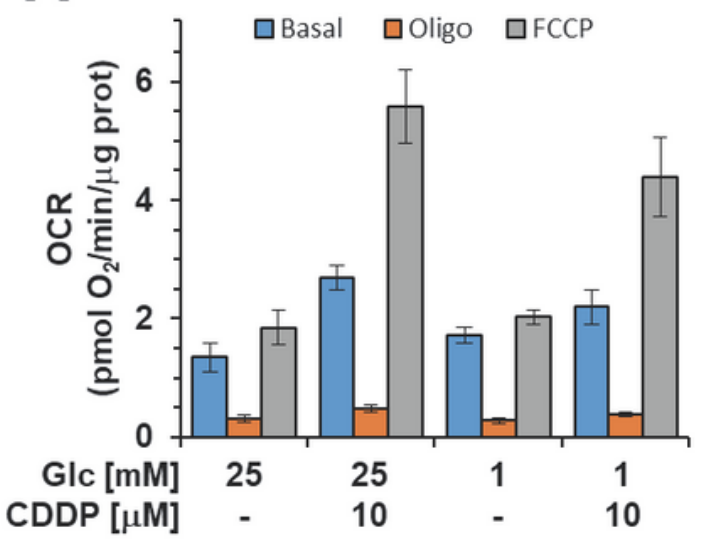

B

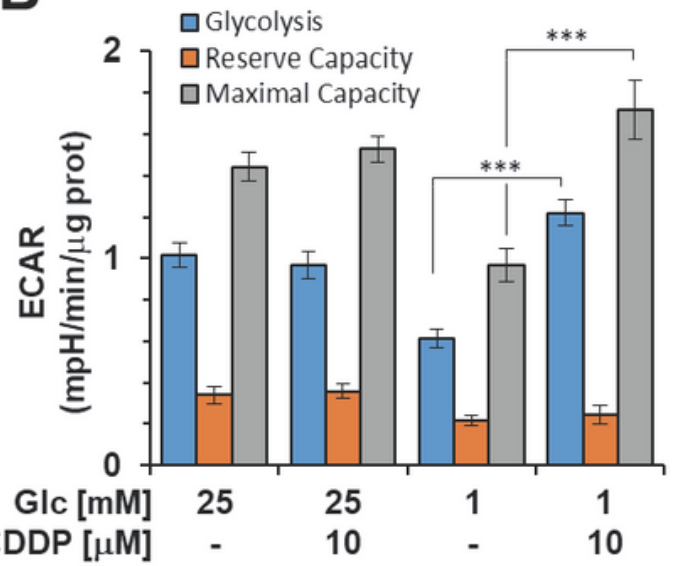

C

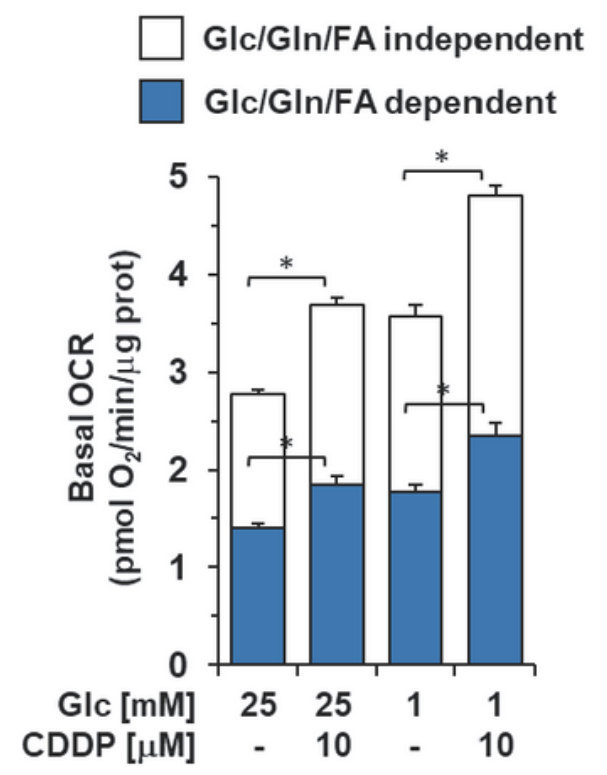

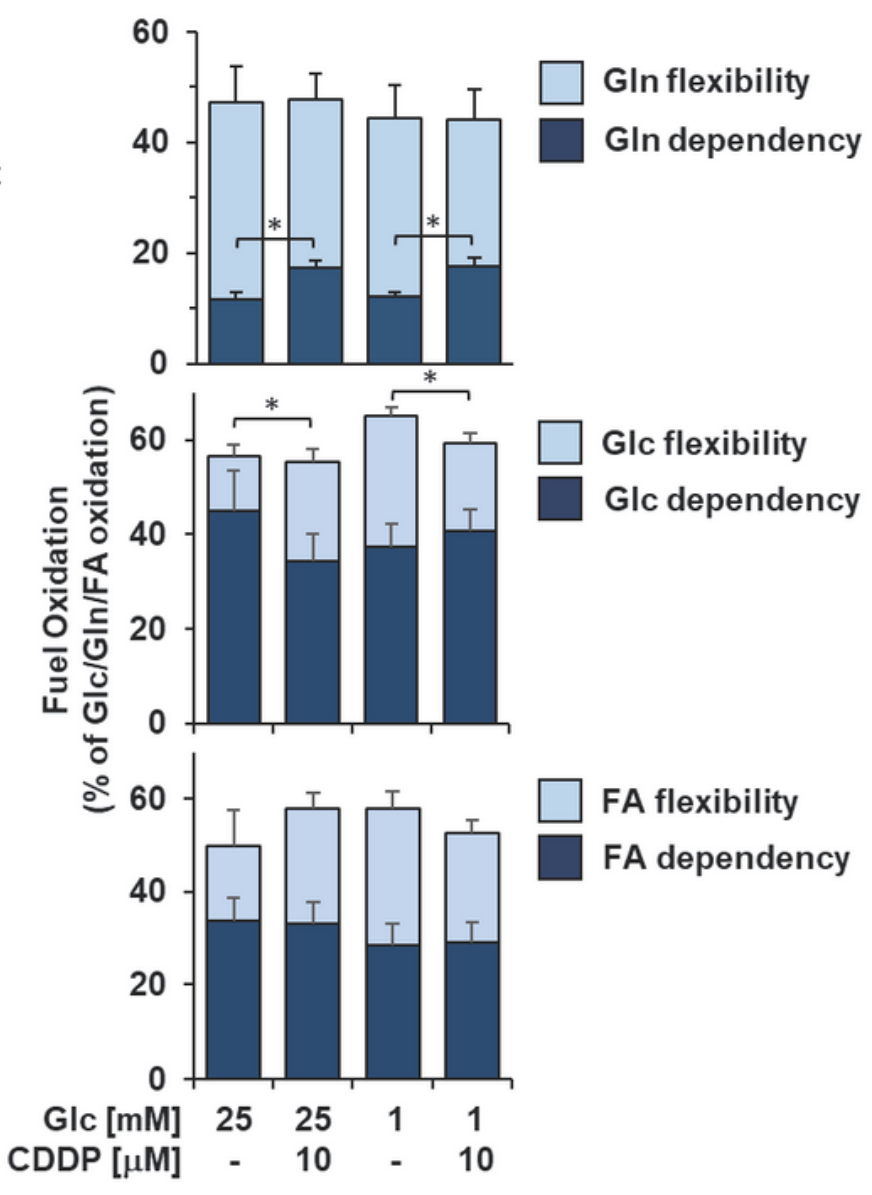

Figure 8 
Cisplatin effects on metabolic fluxes and mitochondrial respiratory activities $3 A B---O S$ CSCs. Cells were incubated $48 \mathrm{~h}$ with $10 \mu \mathrm{M}$ CDDP under high and low glucose growth conditions as indicated and subjected to Seahorse analysis for OCR (A) and ECAR (B) as detailed in Figs. 1A,B. Bar values are means \pm SEM of three independent biological replicates each carried out in triplicate; ${ }^{\star \star *}, p<0,001$. (C) Mitochondrial dependency on and flexibility for oxidation of glucose (Glc), glutamine (GIn), and long chain fatty acids (FA) in presence or absence of CDDP, in high and low glucose nutrient media. The bar histogram on the left shows the combined contribution of glucose (Glc), glutamine (Gln) and long chain fatty acids (FA) to the basal OCR; the residual activity is defined as GIc/GIn/FA---independent OCR. The tripartite bar histograms on the right show the dependency and flexibility of the 3AB---OS OCR relatively to one or the other of Glc, Gln and FA as respiratory substrates. Bar values are means \pm SEM of three independent biological replicates each carried out in triplicate; ${ }^{*}, p<0,005$. See Materials and Methods for further details. 
A

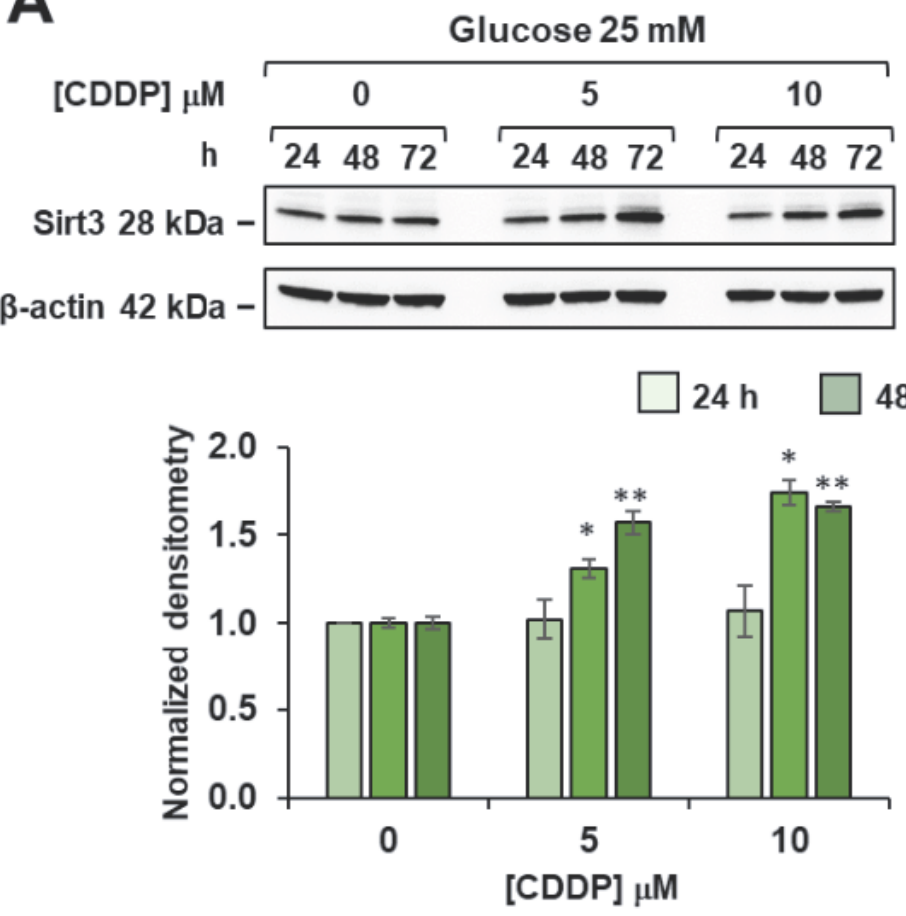

B

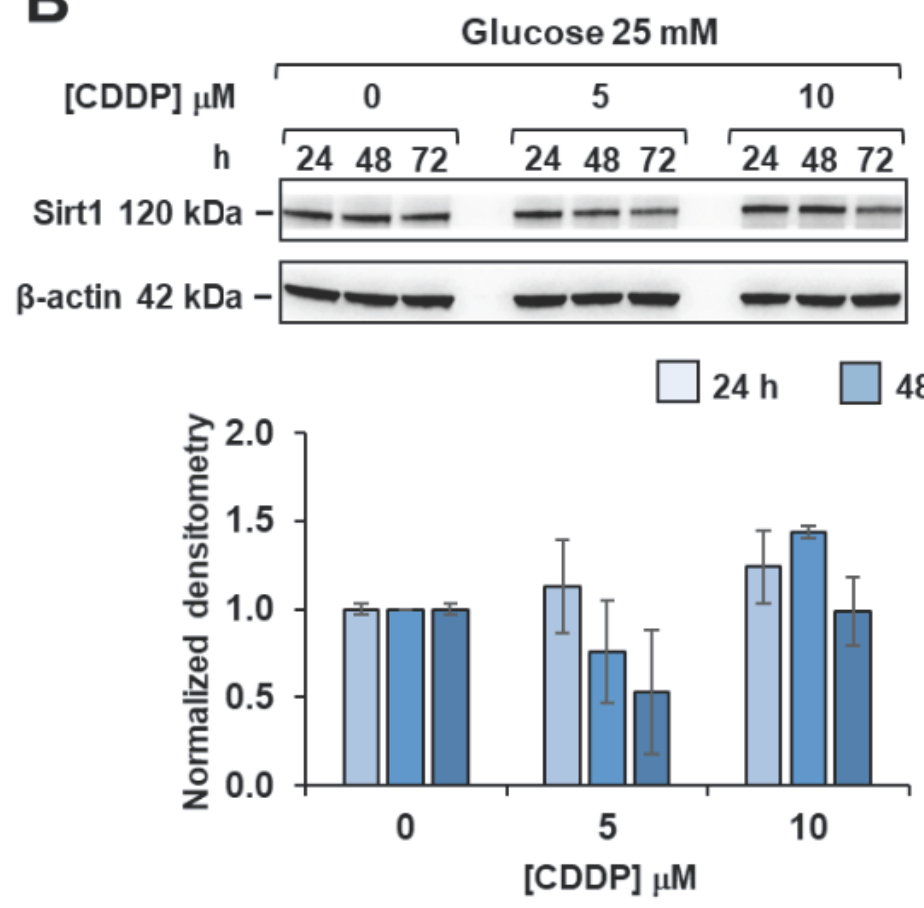

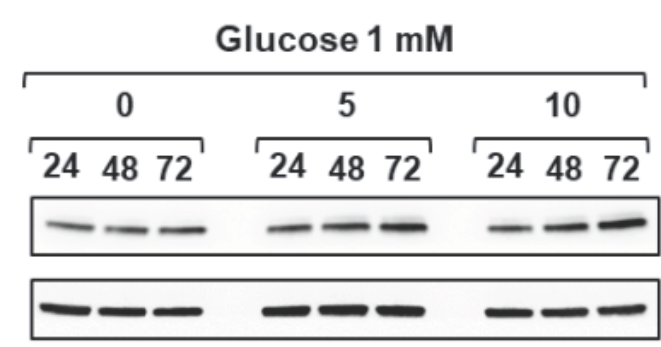

$72 \mathrm{~h}$

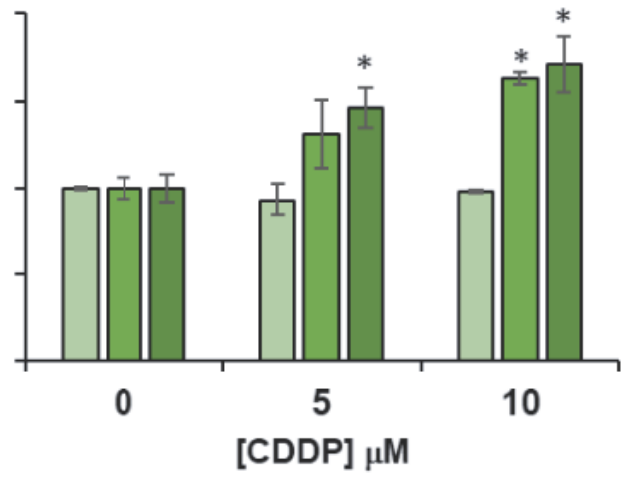

Glucose $1 \mathrm{mM}$

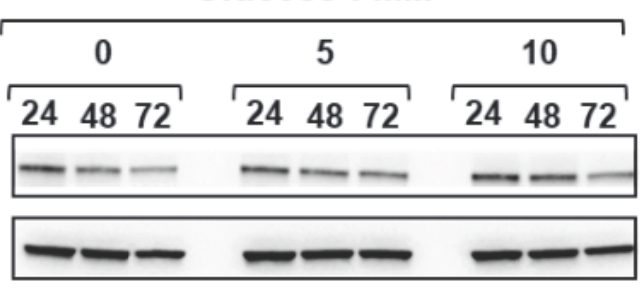

$48 \mathrm{~h} \square 72 \mathrm{~h}$

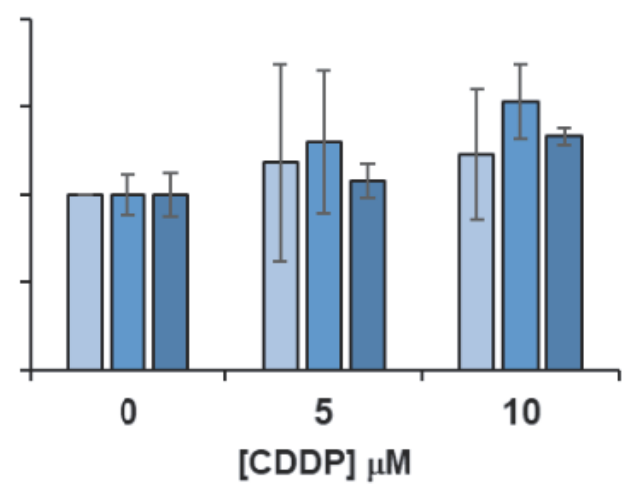

\section{Figure 9}

Effect of cisplatin on sirtuins expression in 3AB---OS under high and low glucose growth conditions. Cells were treated with different concentrations of cisplatin (CDDP) and glucose regimen as indicated; whole cell proteins were extracted at the specified time points and subjected to SDS---PAGE and blotted toward either SIRT3 (A) and SIRT1 (B). Upper panels in (A) and (B) are representative cropped immunoblots of Sirt3 and Sirt1 respectively; lower panels are graph bars showing the average \pm SD of data resulting from 
densitometric analysis (normalized to $\beta$---actin) of three independent biological replicates under each condition. Statistical significances are referred to the relevant controls; ${ }^{*}<<0.05,{ }^{\star *} p<0.01$.

A

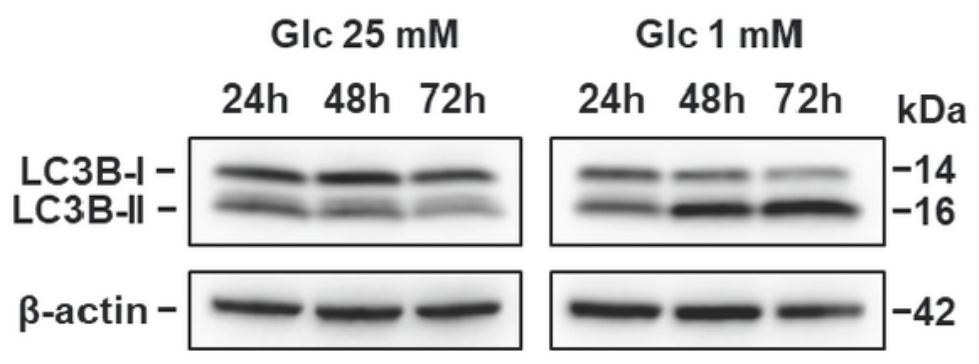

B

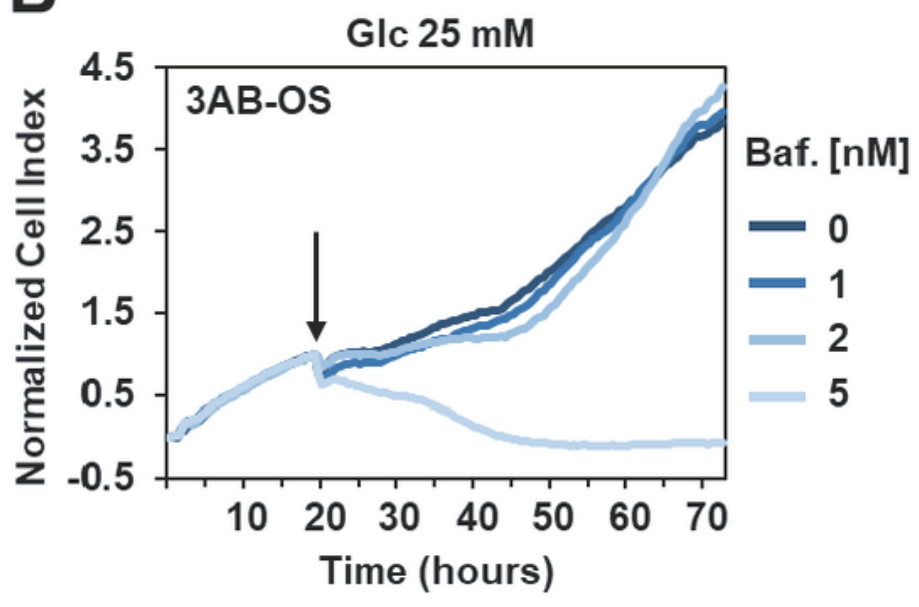

C

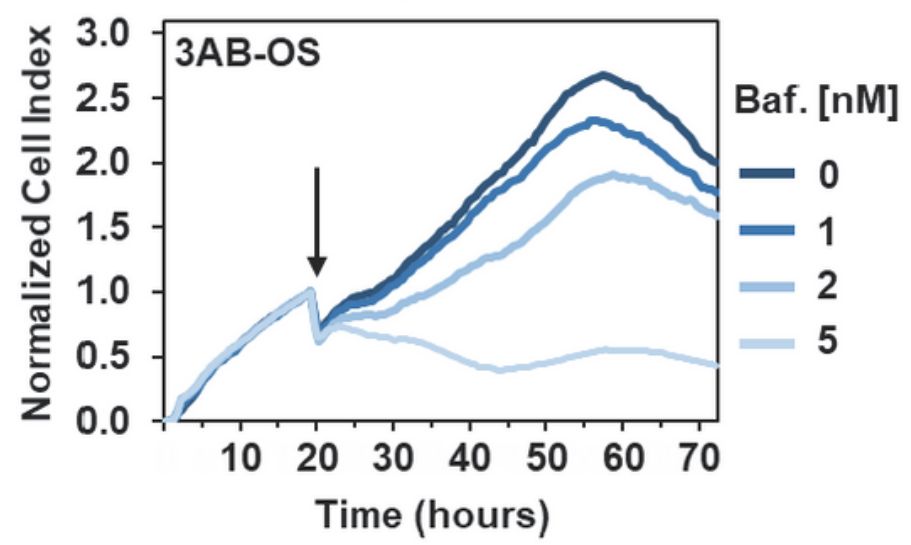

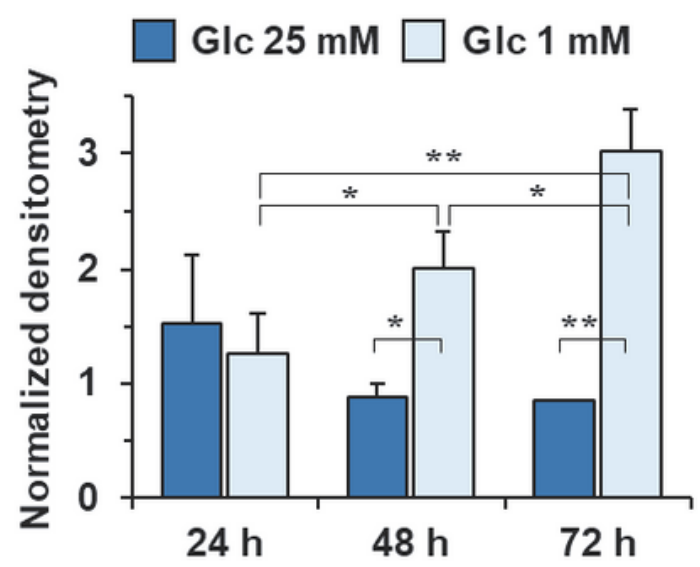
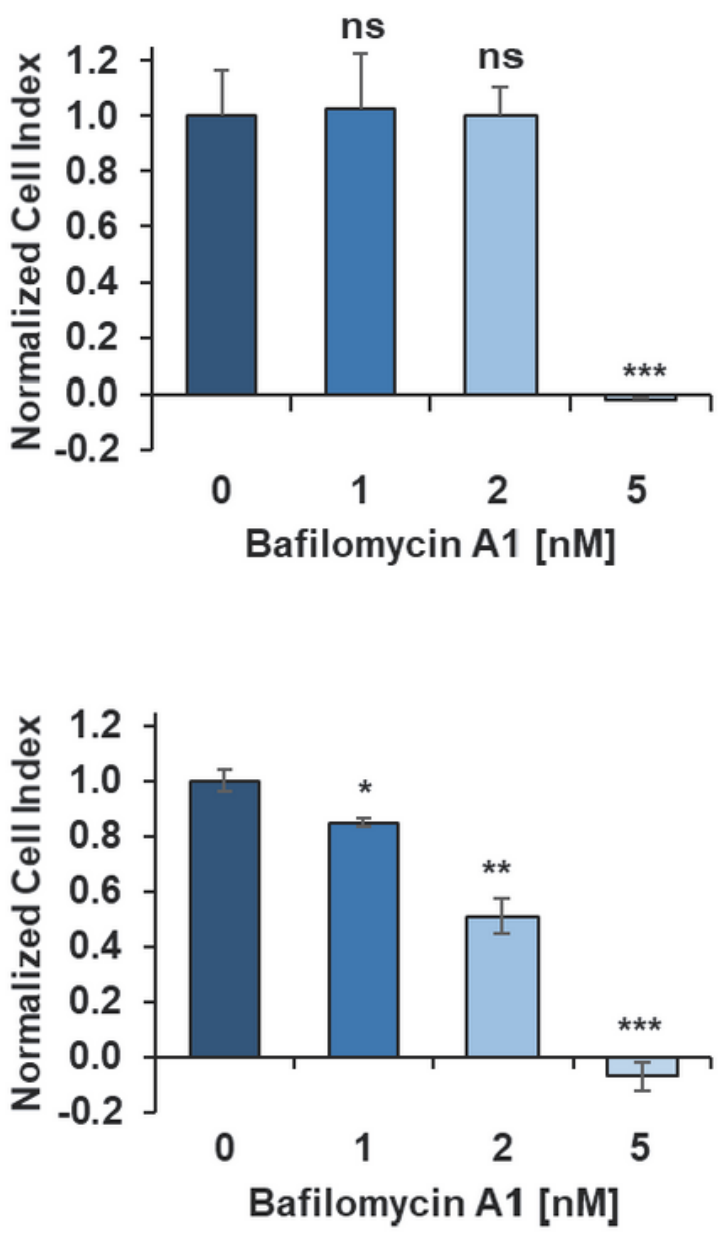

Figure 10

Activation of autophagy flux during glucose starvation in 3AB---OS CSCs. (A) Left panel: representative immunoblotting for protein expression levels of LC3B in high and low glucose, after incubation at 24h, $48 \mathrm{~h}$ and $72 \mathrm{~h}$; $\beta$---actin was used as loading control. Right panel: densitometric analysis displaying 
LC3B---II/LC3B---I ratio (normalized to $\beta$---actin), expressed as mean \pm SD of three independent experiments ( $\mathrm{*}<0.05$, vs respective control Glc $25 \mathrm{mM}$ ). (B) Left panel: representative $\mathrm{NCl}$ traces of 3AB---OS CSCs after exposure to 1, 2, 5 nM bafilomycin A1 (Baf) and vehicle (control). CSCs were cultured for approximately $24 \mathrm{~h}$ in $25 \mathrm{mM}$ Glc DMEM medium, and then treated with the indicated concentrations of Baf 1 in high glucose for $48 \mathrm{~h}$. Right panel: the bar histogram shows $\mathrm{NCl}$ variations after 24h exposure to Baf or vehicle. Data are expressed as mean \pm SD of three independent experiments. Statistical significances are referred to control; $* \star \star \star ~ p<0.0001$. (C) Left panel: representative $\mathrm{NCl}$ traces of 3AB---OS CSCs after exposure to 1, 2, $5 \mathrm{nM}$ bafilomycin A1 (Baf) and vehicle (control). CSCs were cultured for approximately $24 \mathrm{~h}$ in $1 \mathrm{mM}$ Glc DMEM medium, and then treated with the indicated concentrations of Baf in low glucose for $48 \mathrm{~h}$. Right panel: the bar histogram shows $\mathrm{NCl}$ variations after $24 \mathrm{~h}$ exposure to Baf or vehicle. Data are expressed as mean \pm SD of three independent experiments. Statistical significances are referred to control; $* * p<0.01, \star \star \star p<0.0001$.

\section{Supplementary Files}

This is a list of supplementary files associated with this preprint. Click to download.

- GraphicalAbstract.png 